\section{John Ernest Scott 1930-2012}

John Scott was a foremost biomedical research worker in the field of connective tissue for nearly sixty years. As a man born and bred in the Manchester area, and hence in the heart of the British textile industry, perhaps it was only appropriate that his life was spent in elucidating the biochemistry, structure and function of the textiles of the body.

He was a graduate of the University of Manchester: Hons B.Sc. Chemistry \& Physiology, 1951; M. Sc. Physiology, 1953; Ph. D. Chemical Pathology (for which he was awarded the A. V. Hill Prize), 1956; and later, D.Sc. Biochemistry, 1965. His degree courses early indicated his wide scientific interests which were later to progress and merge into the study of structure.

Subsequently, by virtue of his University training, he helped set up the first artificial kidney in the UK, during his National Service in the Royal Air Force as a Pilot Officer. Just as important, one of the fruits of his University research and of considerable medical and commercial significance, was his method for the fractionation and purification of the anti-coagulant heparin, using long-chain quaternary ammonium compounds.

Further development and application of his critical electrolyte concentration principle led to the use of dye-stuffs (Alcian Blue) in the staining of tissue sections for the location of the various proteoglycans at the level of the light microscope, with particular importance for the understanding of cartilage function and the aetiology of osteoarthrosis.

Later, he synthesised electron-dense compounds (Cupromeronic Blue) that permitted the use of the electron microscope to locate and label the polyanions associated with specific cross-bands of the collagen fibril. This close association of collagen and polyanion led him to propose shape modules as the structural and physiological basis for the elasticity required for reversible deformation of connective tissue matrices brought about by movement, loading, swelling, etc.: without these modules, animals would be rigid and immobile.

His concepts and productive work (more than 250 papers) earned him the Gold Medal of the Biochemical Society (1973); the Robert Feulgen Prize of the Gesellschaft fur Histochemie (1986); and the Barbara Robert Memorial Medal of the Société Française du Tissu Conjonctif (2000).

Scott was made an Honorary Member of the Anatomical Society of Great Britain and Ireland (as it then was) in 2000. Additional recognition included other Honorary Memberships: the Société de Dermochemie, Paris (1969); the British Connective Tissue Society (1981); the Società Italiana per lo Studio del
Connettivo (1981); the Czech Medical Society (1985); and the Società Italiana di Istochimica (1989). A long association with the Medical Research Council, from 1960 at the Rheumatism Research Unit at Taplow, was followed by his return to Manchester in 1976 when he was appointed as Honorary Professor of Chemical Morphology, and Emeritus from 1996.

He co-organised a Symposium in 1988 at Vaalsbroek, on the border of Holland and Germany. There I gave the Vote of Thanks and recalled that I had known John for a quarter of a century, at the time when he first introduced me to the CEC-Alcian Blue technique for mucopolysaccharides as they were then called. At a later Symposium in his honour at Varese, Italy, in 1996, I drew the attention of the Conference that that quarter had extended to a third of a century: and that I hoped that this might be lengthened to a half century in the future. Sadly, this was not to be: 2012 is at least one year too early. I and many others have lost a life-long friend and the world a great scientist.

Robin Stockwell FAS Emeritus Professor, University of Edinburgh. 